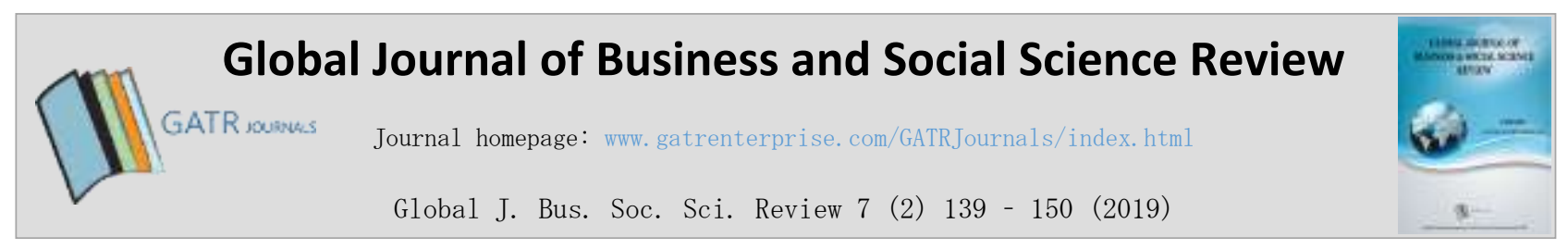

\title{
Construction and Validation of the Learning Management System Success Scale in the Higher Education Setting
}

\author{
Subburaj Alagarsamy, ${ }^{*}$, Margret Vijay ${ }^{2}$ \\ ${ }^{1}$ Institute of Management, Christ (Deemed to be University), Bangalore, 560029, India \\ ${ }^{2}$ Centre for Foundation Studies, Villa College, 20373, Male,' Maldives
}

\begin{abstract}
Objective - The concept of education is entirely outdated. Currently, many higher education institutions are adopting blended learning pedagogy to nurture 21st-century skills. The integration of ICT has become a recent global trend in education with universities and colleges using Learning Management Systems (LMS) as their primary method of disseminating and administrating teaching and learning processes. The exploration of the factors crucial for successful implementation of LMS is therefore essential. However, most literature on this topic focuses on the technical quality of LMS's, and few address the educational quality and efficiency of LMS. Previous research also fails to discuss the conceptualization and measurement of LMS success. This study aims to construct and validate an instrument to measure LMS success in higher education institutions.

Methodology/Technique - Various IS success frameworks were used to design the constructs in this study. A quantitative methodology was adopted with the sample of 379 randomly selected responses from university/college students, academics, and course administrators from India $(\mathrm{n}=297)$ and the Maldives $(\mathrm{n}=82)$. IBM SPSS AMOS 25 was used to check the validity and reliability of the instrument and to identify the measurement invariance.

Findings \& Novelty - This study concludes that information quality, educational quality, system quality, service quality, intention to use, user satisfaction, and net benefits are the critical constructs for measuring LMS success. The findings of this study can be used to support scholars in developing and examining other information system-related theories, as well as to higher education institutions while implementing different LMS's.
\end{abstract}

Type of Paper: Empirical.

Keywords: Learning Management Systems; Invariance; IS Success; Validation; Higher Education.

Reference to this paper should be made as follows: Alagarsamy, S.; Vijay, M. (2019). Construction and Validation of the Learning Management System Success Scale in the Higher Education Setting, Global J. Bus. Soc. Sci. Review 7 (2): 139 - 150 https://doi.org/10.35609/gjbssr.2019.7.2(5)

JEL Classification: A20, A23. A29, I23.

\section{Introduction}

Traditional teaching and learning processes are undergoing a radical transformation as a result of the rapid development of technology in the last two decades, which has shifted the way educational institutions deliver their teaching practices.

\footnotetext{
${ }^{*}$ Paper Info: Revised: March 11, 2019

Accepted: June 22, 2019

* Corresponding author: Subburaj Alagarsamy

E-mail: subbu2raj@gmail.com

Affiliation: Institute of Management, Christ (Deemed to be University), Bangalore, India
} 
The communication between teachers and students is better facilitated through closer integration of the educational environment and ICTs (Fardoun et. al., 2009; Wang et. al., 2014). However, the challenges of the implementation of ICT have also increased. Integrating ICT in education through innovative pedagogical methods (such as virtual classrooms, flipped classrooms etc.) is another recent trend in education. Almost all institutions have adopted the Learning Management System (LMS) as their primary information system to disseminate advanced learning cultures (Weaver et. al., 2008; Hafiz Zakaria et. al., 2010). LMS (Moodle, Blackboard, Canvas, etc.) enables e-learning through innovative teaching and interactive learning activities along with efficient course administration and communication features. The implementation of LMS has been rapid in many higher education institutions around the world. As a result, it is now an indispensable part of many curriculums for content delivery, course evaluation, and administration. It also provides easy access to course materials, which leads to better academic performance (Sayfouri, 2016; Arenas-Gaitán et. al., 2018). It has been predicted that the largest online company in 2030 will be an education-based company (Schaefer et. al., 2012).

According to Stone and Zheng (2014, p12), "LMS is a centralized web-based information system where the learning content is managed, and learning activities are organized." Online learning content is accessed through the LMS, which enables students to view and communicate using any personal computer or mobile device. Furthermore, the LMS incorporates features such as learning structures, course management, content administration, student portal, and instructional administration systems (Sayfouri, 2016; Hafiz Zakaria et. al., 2010). It facilitates higher education institutions to enroll students in a particular module and track students' activities (Horvat et. al., 2015). Due to global educational demands, educational institutions are creating different educational choices to empower students through e-learning applications. Some educational certifications demand the inclusion of blended learning (online exams, simulations) in their regular curriculum. Furthermore, an LMS enables students to access information such as course outlines, assignment submission guidelines, links, obtaining course assessment feedback, dynamic interactions between students and lecturers, connections between students, and online exams (Wang et. al., 2012).

Without a doubt, the rise of modern discoveries has facilitated the delivery of equal educational opportunity to all people, irrespective of their geographical or economic divide. Undeniably, in the absence of an analysis of the essential requirements of teaching and learning, the use or implementation of such advanced technologies in education would be less than optimal. In such cases, the technology might be used as a marketing tool only and not as an educational tool. Since the ineffective or unsuccessful implementation of LMS in educational institutions may lead them to choose not to adopt the systems, the success of an LMS must be assessed beforehand. Most research on LMS focuses only on teachers and students in LMS evaluation. However, according to Bhuasiri et. al. (2012) and Kasim and Khalid (2016), stakeholders other than students are essential to an evaluation of the success of LMS. Innovations such as the internet, 3D technology, augmented reality, and other digital technologies optimize LMS into a flexible and collaborative environment. Due to the rise of global educational demands for innovative pedagogies, blended learning and e-learning require a detailed evaluation to ensure the objectives of teaching in higher education are achieved.

There are many LMS's available in different variants. Therefore, it is crucial to explore the critical factors that affect the success of LMS (Kasim \& Khalid, 2016). Most of the literature focuses on perceived usefulness, perceived ease of use, users' attitude toward technology and behavioral intentions only (Wang et. al., 2007; Wang \& Wang, 2009; Lee, 2010; Bhuasiri et. al., 2012). However, those studies fail to address the conceptualization and measurement of LMS success from an educational viewpoint.

\section{Literature Review}

This study aims to construct and validate an instrument to measure LMS success in a higher educational setting. The theoretical context of the research is adopted from different research lines based on the information system (IS) point of view. The adaptation of LMS, continuous usage and LMS success was addressed using different models such as the revised DeLone and McLean Information System Success

Global J. Bus. Soc. Sci. Review 7 (2) 139 -150 (2019) 
Model (2003), Holsapple and Lee- Post's E-learning Success Model (2006), Lin and Lee's Online Communication Success Model (2006), Lin's Measuring Online Learning System Success Model (2007) and Hassanzadeh, Kanaani and Elahi’s Measuring E-learning Systems Success Models (2012).

\subsection{Model Comparison}

One of the most cited (Google Scholar Records, 21755 citations) and extensively applied theories in the field of the information systems (IS) is the Delone and McLean Information System Success Model (DeLone $\&$ McLean, 1992), which provides a comprehensive understanding of information system success. The initial model includes six separate components of information systems success (DeLone \& McLean, 1992): "System Quality, Information Quality, Use, User Satisfaction, Individual Impact, and Organisational Impact." Following from this, the Updated D\&M Information Systems Success Model was introduced with an additional factor: service quality (Delone \& McLean, 2003). Over time, the D\&M Information Systems Success Model has been revised by the authors to fit the specifications set by different characteristics of information systems and from various points of view (Klobas \& McGill 2010; Hassanzadeh et. al., 2012; Ramírez-Correa et. al., 2017; Arenas-Gaitán et. al., 2018). The initial DeLone and McLean (1992) model used the organizational output as an outcome of information system success, and an update, the DeLone, and McLean (2003) model were reconstructed into net benefits which can be suitable for all information system settings.

Holsapple and Lee-Post (2006) modified the D\&M Information Systems Success Model to assess elearning programs. The e-learning success model by Holsapple and Lee-Post (2006) includes aspects such as technical quality, information quality, service quality, user satisfaction, use, and net benefits, but failed to cover the educational quality of the e-learning systems. The interrelationship between the components is also not explained. Later, Lin and Lee's (2006) study recommended a revised model to explore the determinants for the successful use of online communities using the D\&M Information Systems Success Model. Their online communication success model follows similar components as the modified D\&M Information Systems Success Model. However, this model also fails to discuss the educational quality and net benefit component. Instead of measuring net benefit, this model uses user loyalty dimensions, which provides a similar understanding of net benefits. Other than these changes, this model is almost the same as the modified D\&M Information Systems Success Model. All the above models were grounded on both the old and updated DeLone, and McLean (1992, 2003) Information Systems Success Models. However, both the old and updated D\&M Information Systems Success Models were designed to check the success of the information system in general, not particularly to assess the LMS or other e-learning systems; hence the educational quality was not discussed in any of these models.

Lin (2007) also revised the D\&M Information Systems Success Model to assess the effectiveness of online learning practices. This online learning system success model does not have the educational quality or net benefit component; it is very similar to the modified D\&M Information Systems Success Model. Further, Hassanzadeh et. al. (2012) adopted the D\&M Information Systems Success Model to measure the success of e-learning systems in universities with additional dimensions. According to Hassanzadeh et. al. (2012), the elearning systems success models is the most suitable model to assess the success of e-learning and LMS because this model includes additional components such as educational quality, user loyalty, and goal achievement. In addition, this model considers the relationship between the components and takes into account the intention to use and use as two separate components.

Lin and Lee's (2006) and Wang and Liao's (2008) studies reveal that user loyalty is measured using indicators such as user dependency, user involvement, and participation in an information system. On the other hand, Wang et. al. (2007) measures system dependency using the intention to use (system use) component, and user involvement in information systems is measured using user satisfaction by assessing perceived utility. Alternatively, user participation is measured using the intention to use in terms of voluntary use. 
Hassanzadeh et. al.'s (2012) study estimates that goal achievement indicates the achievement of personal and educational goals. In the same study, educational quality was also assessed by evaluating learning, the performance of the system, collaborativeness, and active learning, which is similar to goal achievement. From this, it is apparent that the modified D\&M Information Systems Success Model is the best model to assess LMS success if the educational quality component is included. As per Hassanzadeh et. al. (2012), while measuring e-learning systems success, an additional dimension such as user loyalty and goal achievements are considered an internal part of educational quality, user satisfaction and intention to use components. The addition of these components to the existing modified D\&M Information Systems Success Model may affect the primary goal of research by confusing the respondents, which will affect the validity and reliability of the instrument.

\subsection{Construct Development}

Based on the various models found within the literature, the research instrument was developed to assess the success of Learning Management Systems in higher education institutions. Based on previous studies, the constructs and indicators of the proposed instrument are determined.

Table 1. Indicators Measuring LMS Success

\begin{tabular}{|c|c|c|c|}
\hline Constructs & Meaning & Indicators & Reference \\
\hline $\begin{array}{l}\text { Technical } \\
\text { System } \\
\text { Quality }\end{array}$ & $\begin{array}{l}\text { The technical } \\
\text { and LMS system } \\
\text { performance }\end{array}$ & $\begin{array}{l}\text { LMS availability, ease of } \\
\text { use, user-friendliness, high- } \\
\text { speed access to information, } \\
\text { attractive features, } \\
\text { reliability, and security }\end{array}$ & $\begin{array}{l}\text { Delone and McLean (2003), Hassanzadeh } \\
\text { et. al. (2012), Ho and Dzeng (2010), Wang } \\
\text { et. al., (2014); Holsapple and Lee-Post, } \\
\text { (2006), Arenas-Gaitán et. al. (2018), } \\
\text { Klobas and McGill (2010), Lin, (2007); } \\
\text { Wang et. al. (2007), Lin and Lee (2006), } \\
\text { Ozkan and Koseler, (2009), Ramírez- } \\
\text { Correa et. al. (2017), Wang and Liao } \\
\text { (2008), Wang and Wang (2009) }\end{array}$ \\
\hline $\begin{array}{l}\text { Educational } \\
\text { System } \\
\text { Quality }\end{array}$ & $\begin{array}{ll}\text { Features } & \text { that } \\
\text { enable } & \\
\text { innovative } & \\
\text { teaching } & \text { and } \\
\text { learning } & \\
\text { pedagogies } & \end{array}$ & $\begin{array}{l}\text { Appropriateness to the } \\
\text { context/pedagogies, } \\
\text { effective collaboration, } \\
\text { effective interaction } \\
\text { between users, evaluation } \\
\text { of learning performance and } \\
\text { personalized information } \\
\text { presentation }\end{array}$ & $\begin{array}{l}\text { Weaver et. al. (2008), Fardoun (2009), } \\
\text { Ginns and Ellis, (2009), Hassanzadeh et. } \\
\text { al. (2012), Lee (2010), Lin (2007), Pituch } \\
\text { and Lee (2006), }\end{array}$ \\
\hline $\begin{array}{l}\text { Information } \\
\text { Quality }\end{array}$ & $\begin{array}{lr}\text { LMS } & \text { output } \\
\text { quality and } \\
\text { measures } \\
\text { semantic success }\end{array}$ & $\begin{array}{l}\text { Usefulness, updated } \\
\text { information, accuracy and } \\
\text { precise information, better } \\
\text { display, useful format, and } \\
\text { organized content }\end{array}$ & $\begin{array}{l}\text { Delone and McLean (2003), Hassanzadeh } \\
\text { et. al. (2012), Ho and Dzeng (2010), Wang } \\
\text { et. al. (2014); Holsapple and Lee-Post, } \\
\text { (2006), Arenas-Gaitán et. al. (2018), } \\
\text { Klobas and McGill (2010), Lin, (2007); } \\
\text { Wang et. al. (2007), Lin and Lee (2006), } \\
\text { Ozkan and Koseler, (2009), Ramírez- } \\
\text { Correa et. al. (2017), Wang and Liao } \\
\text { (2008), Wang and Wang (2009) }\end{array}$ \\
\hline $\begin{array}{l}\text { Service } \\
\text { Quality }\end{array}$ & $\begin{array}{l}\text { The support } \\
\text { delivered to } \\
\text { LMS users to } \\
\text { assist their use of } \\
\text { the LMS }\end{array}$ & $\begin{array}{l}\text { Better support by staffs on } \\
\text { explanation, staff } \\
\text { availability, interaction by } \\
\text { the team on LMS } \\
\text { development, suggestion on }\end{array}$ & $\begin{array}{l}\text { Delone and McLean (2003), Hassanzadeh } \\
\text { et. al. (2012), Holsapple and Lee-Post } \\
\text { (2006), Klobas and McGill (2010), Lin } \\
\text { (2007), Wang and Wang (2009), Wang et. } \\
\text { al. (2007); Wang et. al. (2014) }\end{array}$ \\
\hline
\end{tabular}




\begin{tabular}{|c|c|c|c|}
\hline & & future enhancement & \\
\hline $\begin{array}{l}\text { Intention to } \\
\text { Use/ Use }\end{array}$ & $\begin{array}{l}\text { Perceived user } \\
\text { behavior of LMS } \\
\text { using/willingness } \\
\text { to use the LMS }\end{array}$ & $\begin{array}{l}\text { The frequency of use, } \\
\text { dependency, voluntary, } \\
\text { mandatory and intent to use }\end{array}$ & $\begin{array}{l}\text { Delone and McLean (2003), Hassanzadeh } \\
\text { et. al. (2012), Ho and Dzeng (2010), Wang } \\
\text { et. al. (2014); Holsapple and Lee-Post, } \\
\text { (2006), Arenas-Gaitán et. al. (2018), } \\
\text { Klobas and McGill (2010), Lin, (2007); } \\
\text { Wang et. al. (2007), Lin and Lee (2006), } \\
\text { Ozkan and Koseler, (2009), Ramírez- } \\
\text { Correa et. al. (2017), Wang and Liao } \\
\text { (2008), Wang and Wang (2009) }\end{array}$ \\
\hline $\begin{array}{l}\text { User } \\
\text { Satisfaction }\end{array}$ & $\begin{array}{l}\text { The overall } \\
\text { satisfaction and } \\
\text { attitude of the } \\
\text { LMS users on } \\
\text { the LMS }\end{array}$ & $\begin{array}{l}\text { System efficiency, user } \\
\text { confidence, user needs, } \\
\text { positive attitude, perceived } \\
\text { utility, user satisfaction, } \\
\text { recommending others }\end{array}$ & $\begin{array}{l}\text { Arenas-Gaitán et. al. (2018), Delone and } \\
\text { McLean (2003), Hassanzadeh et. al. } \\
\text { (2012), Holsapple and Lee-Post (2006), } \\
\text { Klobas and McGill (2010), Lee (2010), Lin } \\
\text { (2007), Lee (2010), Ramírez-Correa et. al. } \\
\text { (2017), Wang and Wang (2009), Wang et. } \\
\text { al. (2007); Wang et. al. (2014) }\end{array}$ \\
\hline Net benefit & $\begin{array}{l}\text { The user benefits } \\
\text { resulting from } \\
\text { the use of the } \\
\text { LMS }\end{array}$ & \begin{tabular}{lr} 
Improved & learning \\
performance, & \multicolumn{2}{c}{ problem- } \\
solving, quick response, \\
enhancement in the \\
$\begin{array}{l}\text { competitiveness of the } \\
\text { college }\end{array}$
\end{tabular} & $\begin{array}{l}\text { Arenas-Gaitán et. al. (2018), Delone and } \\
\text { McLean (2003), Hassanzadeh et. al. } \\
\text { (2012), Holsapple and Lee-Post (2006), } \\
\text { Ramírez-Correa et. al. (2017), Wang and } \\
\text { Liao (2008), Wang and Wang (2009), } \\
\text { Wang et. al. (2007); Wang et. al. (2014) }\end{array}$ \\
\hline
\end{tabular}

\section{Research Methodology}

This study follows objectivity ontology and positivism epistemology. Since this study aims to construct and validate the instrument to measure LMS success in a higher educational institutions using various theories, the deductive approach was followed (Lin 2007; Wang \& Wang 2009; Wang et. al. 2007; Wang et. al. 2014). A quantitative methodology was adopted with a sample size of 379 randomly selected responses from university/college students, academics, and course administrators from India $(n=297)$ and the Maldives $(\mathrm{n}=82)$. A well-structured questionnaire was used to measure LMS success, and the instrument was adopted from multiple previous studies (see Table 1; Appendix 1). The present instrument is a self-administered scale consisting of 44 items developed to assess LMS success. Participants are asked to indicate on a seven-point scale (1-strongly disagree, 7-strongly agree) based on their level of agreement about the LMS success components. IBM SPSS AMOS 25 was used to check the reliability, validity, and measurement invariance of the instrument. The sample consists of 53\% academics, $32 \%$ students, and $15 \%$ course administrators. Of all the participants, $27 \%$ were from science and engineering disciplines, and $73 \%$ were from the arts, social science, and humanities disciplines.

\section{Results}

\subsection{Validity and Reliability Analysis}

Cronbach's Alpha coefficient $(\alpha)$ is used to estimate the internal reliability of the instrument (Nunnally, 1978). Confirmatory Factor Analysis (CFA) is primarily used to define the factor structure of the data. Since the instrument was adopted from various studies and the factor structures were specified in the instrument, the exploratory factor analysis was not conducted, and CFA was used to confirm the defined factor structure (Brown, 2006). This study allows us to check the convergent and discriminant validity, as well as the reliability of the research instrument. Construct validity indicates that a questionnaire intends to assess a distinct construct (i.e., educational quality) is estimating that construct. Convergent validity means variables 
are correlated adequately with each other within their parent constructs, and the latent factor is explained well by the observed variables. Conversely, discriminant validity of the underlying factor is adequately described by other variables rather than by its observed variables. Both validities are essential for optimum construct validity (Campbell \& Fiske, 1959). Composite Reliability (CR), Average Variance Extracted (AVE) and Maximum Shared Variance (MSV) are primarily used for confirming validity and reliability (Hair et. al., 2013).

Table 2. Reliability and Validity Measures

\begin{tabular}{|c|c|c|c|c|c|c|c|c|c|c|c|}
\hline Code & $\beta$ & $\mathrm{CR}(\alpha)$ & AVE & MSV & NB & IQ & TSQ & US & SQ & ESQ & ITU \\
\hline NB1 & .790 & \multirow{8}{*}{$\begin{array}{l}.917 \\
(.910)\end{array}$} & \multirow{8}{*}{.583} & \multirow{8}{*}{.439} & \multirow{8}{*}{.763} & & & & & & \\
\hline NB2 & .820 & & & & & & & & & & \\
\hline NB3 & .880 & & & & & & & & & & \\
\hline NB4 & .600 & & & & & & & & & & \\
\hline NB5 & .870 & & & & & & & & & & \\
\hline NB6 & .690 & & & & & & & & & & \\
\hline NB7 & .740 & & & & & & & & & & \\
\hline NB8 & .670 & & & & & & & & & & \\
\hline IQ1 & .700 & \multirow{8}{*}{$\begin{array}{l}.906 \\
(.901)\end{array}$} & \multirow{8}{*}{.552} & \multirow{8}{*}{.441} & \multirow{8}{*}{$.583 * *$} & \multirow{8}{*}{.743} & & & & & \\
\hline IQ2 & .750 & & & & & & & & & & \\
\hline IQ3 & .730 & & & & & & & & & & \\
\hline IQ4 & .620 & & & & & & & & & & \\
\hline IQ5 & .870 & & & & & & & & & & \\
\hline IQ6 & .510 & & & & & & & & & & \\
\hline IQ7 & .800 & & & & & & & & & & \\
\hline IQ8 & .880 & & & & & & & & & & \\
\hline TSQ1 & .850 & \multirow{6}{*}{$\begin{array}{l}.916 \\
(.912)\end{array}$} & \multirow{6}{*}{.646} & \multirow{6}{*}{.230} & \multirow{6}{*}{$.404 * *$} & \multirow{6}{*}{$.436 * *$} & \multirow{6}{*}{.803} & & & & \\
\hline TSQ2 & .730 & & & & & & & & & & \\
\hline TSQ3 & .870 & & & & & & & & & & \\
\hline TSQ4 & .800 & & & & & & & & & & \\
\hline TSQ5 & .740 & & & & & & & & & & \\
\hline TSQ6 & .830 & & & & & & & & & & \\
\hline US1 & .800 & \multirow{6}{*}{$\begin{array}{l}.906 \\
(.902)\end{array}$} & \multirow{6}{*}{.621} & \multirow{6}{*}{.446} & \multirow{6}{*}{$.586 * *$} & \multirow{6}{*}{$.554 * *$} & \multirow{6}{*}{$.479 * *$} & \multirow{6}{*}{.788} & & & \\
\hline US2 & .730 & & & & & & & & & & \\
\hline US3 & .890 & & & & & & & & & & \\
\hline US4 & .830 & & & & & & & & & & \\
\hline US5 & .590 & & & & & & & & & & \\
\hline US6 & .860 & & & & & & & & & & \\
\hline SQ1 & .860 & \multirow{5}{*}{$\begin{array}{l}.892 \\
(.889)\end{array}$} & \multirow{5}{*}{.625} & \multirow{5}{*}{.485} & \multirow{5}{*}{$.612 * *$} & & & & & & \\
\hline SQ2 & .740 & & & & & & & & & & \\
\hline SQ3 & .800 & & & & & $.629^{* *}$ & $.413^{* *}$ & $.668 * *$ & .790 & & \\
\hline SQ4 & .670 & & & & & & & & & & \\
\hline SQ5 & .870 & & & & & & & & & & \\
\hline
\end{tabular}




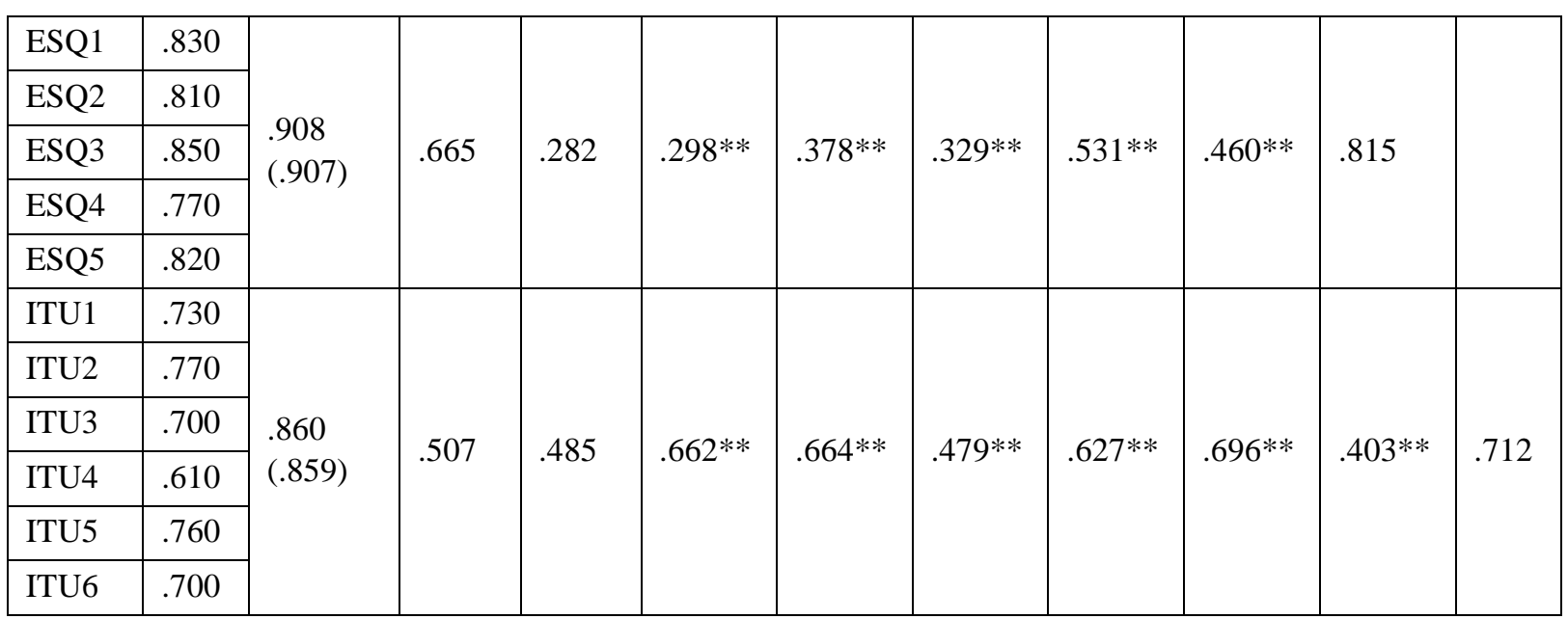

Note: **p<0.01; NB, Net Benefits; IQ, Information Quality; TSQ, Technical System Quality; US, User Satisfaction; SQ, Service Quality; ESQ, Educational System Quality; ITU, Intention To Use; $\beta$, Standardised Beta; CR, Composite Reliability; $\alpha$, Cronbach Alpha Coefficient; AVE, Average Variance Extracted; MSV, Maximum Shared Variance.

The Cronbach alpha coefficient for all constructs was more than $.80(\mathrm{CR}>0.7)$. Table 2 shows that the standardized loading estimates $(\beta)$ are above 0.5 and significant at $1 \%$. The properties of the measurement model were evaluated using composite reliability (CR) and convergent validity (Hair et. al., 2013; Baalbaki et. al., 2013). All constructs exhibited CR with the minimum acceptable level of 0.7 (CR > 0.7), indicating good composite reliability. The Average Variance Extracted (AVE) measure is assessed for the estimation of scales' convergent validity (Fornell \& Larcker, 1981). The latent construct's AVE values must be greater than 0.5 (AVE > 0.5) so that at least half of the variance among the indicators can be explained in the research (Hair et. al., 2013). The Average Variance Extracted values (0.5) for all constructs are higher than normal levels (see Table 3). This supports the convergent validity of the constructs. Table 2 shows that MSV is less than AVE, AVE and the square root of AVE are greater than the inter-construct correlations, which supports the discriminant validity of the construct (Hair et. al., 2013; Baalbaki et. al., 2013). The above table supports the validity of the constructs and reliability of the instrument. $\chi 2 / D . F$ (between 1 and 3), Comparative Fit Index (CFI $\geq 0.95$ ), Standardised Root Mean square Residual (SRMR <0.08) and Root Mean Square Error of Approximation (RMSEA $<0.06)$ are used as indicators of good fit (Hu \& Bentler, 1999). These indexes are the most commonly published model fit indices when the sample size is small. $\chi 2 / \mathrm{D} . \mathrm{F}=1.571 ; \mathrm{CFI}=0.954 ; \mathrm{SRMR}=0.043$; and RMSEA $=0.039$. These results indicate that the measurement model is a good fit.

\subsection{Measurement Invariance}

The measurement model formalizes the relationship between the latent construct and the indicators that could be assessed using confirmatory factor analysis. Factor loadings and intercepts that link each item to the latent construct are the main parameters of the measurement model (Kühne, 2017). The invariance could be examined against each measurement parameter. There are different types of measurement invariances such as configurable invariance, metric invariance, and scalar invariance. Configurable invariance means both samples associate the same subsets of items with the same constructs. Metric invariance means that overall, the strength of the relationships between the items and their underlying latent constructs are the same for both groups. Scalar invariance means all items indicate the same cross-cultural differences and relationships among the constructs of the same groups (Cheung \& Rensvold, 2002).

These results show that the measurement model is supported in both the Indian and Maldivan groups. These finding establish configurable invariance, meaning the model is the best fit for both samples 
$(\chi 2 / \mathrm{D} . \mathrm{F}=1.49$; comparative fit index $(\mathrm{CFI})=.925 ; \mathrm{TLI}=0.919$; RMSEA=.036). Further, it also confirms that both the Indian and Maldivan samples have the same level of conceptualization in LMS success. The configure invariance is supported, and the metric invariance is good, as evidenced by a non-significant $\Delta \chi 2$ test $(\Delta \chi 2=36.273 ; \mathrm{p}=0.503 ; \Delta \mathrm{TLI}=-.002)$ between the unconstrained and fully constrained models where the regression weights were constrained, signifying that the indicators have equivalent salience for the Indian and Maldivian samples.

Table 3. Measurement Invariance Tests

\begin{tabular}{|l|l|l|l|l|l|l|l|}
\hline \multirow{2}{*}{ Models } & \multicolumn{2}{|l|}{ Model fit statistics } & \multicolumn{2}{l|}{ Change of model fit statistics } \\
\cline { 2 - 8 } & $\chi 2(\mathrm{D} . \mathrm{F})$ & $\chi 2 / \mathrm{D} . \mathrm{F}$ & $\mathrm{TLI}$ & RMSEA & $\begin{array}{l}\Delta \chi 2 \\
(\Delta \mathrm{D} . \mathrm{F})\end{array}$ & $\mathrm{p}$ value & $\Delta$ TLI \\
\hline $\begin{array}{l}\text { Hypothesized } \\
\text { measurement model }\end{array}$ & $\begin{array}{l}1383.92 \\
(881)\end{array}$ & 1.571 & 0.951 & 0.039 & & & \\
\hline Configurable invariance & $\begin{array}{l}2616.97 \\
(1762)\end{array}$ & 1.485 & 0.919 & 0.036 & & & \\
\hline $\begin{array}{l}\text { Construct-level metric } \\
\text { invariance }(\Lambda \mathrm{I}=\Lambda \mathrm{M})\end{array}$ & $\begin{array}{l}2653.24 \\
(1799)\end{array}$ & 1.475 & 0.925 & 0.035 & $\begin{array}{l}36.273 \\
(37)\end{array}$ & 0.503 & -0.002 \\
\hline $\begin{array}{l}\text { Intercept scalar invariance } \\
(\square \mathrm{I}=\square \mathrm{M})\end{array}$ & $\begin{array}{l}2716.9 \\
(1843)\end{array}$ & 1.474 & 0.923 & 0.035 & $\begin{array}{l}99.926 \\
(81)\end{array}$ & 0.075 & -0.002 \\
\hline $\begin{array}{l}\text { Equivalence of construct } \\
\text { covariance }(\Phi \mathrm{I}=\Phi \mathrm{M})\end{array}$ & $\begin{array}{l}2744.87 \\
(1871)\end{array}$ & 1.467 & 0.923 & 0.035 & $\begin{array}{l}127.9 \\
(109)\end{array}$ & 0.104 & -0.003 \\
\hline
\end{tabular}

Note: $\Delta \chi 2$, change in chi-square; $\Delta \mathrm{D} . \mathrm{F}$, change in degrees of freedom; and $\Delta \mathrm{TLI}$, Tucker-Lewis index between each hierarchical model; $\Lambda$, factor loading; intercept; $\Phi$, covariance matrix; I, Indian; M, Maldivian; RMSEA, Root Mean Square Error of Approximation.

The model also has good metric invariance meaning it can be used to assess scalar invariance. The scalar invariance is supported and intercepts $(\Delta \chi 2=99.926 ; \mathrm{p}=0.075 ; \Delta \mathrm{TLI}=-.002)$ and structural covariance $(\Delta \chi 2=127.9 ; \mathrm{p}=0.104 ; \Delta \mathrm{TLI}=-.003)$ are equivalent across the groups as evidenced by the non-significant $\Delta \chi^{2}$ test. The three types of measurement invariance were also supported (see Table 3). Given the level of measurement invariance supported in the analysis, we can confidently say that the LMS success factor structure and loadings are equivalent across the Indian and Maldivan groups and can be used to measure the same underlying latent constructs for both groups.

\section{Discussion and Implications}

In higher education, e-learning opportunities are expanding exponentially. Higher educational institutions have already started to redefine how they deliver their knowledge innovatively by integrating factors that influence student satisfaction. This approach helps those institutions to redesign their e-learning environments with successful information systems and LMS to enhance the teaching and learning process. The factors that influences the characteristics of academics, students, and the teaching-learning process in the LMS environment must be studied (Arenas-Gaitán et. al., 2018). Before implementing any LMS (Moodle, Blackboard, Canvas, etc.,), it is essential to determine the usability of the application and to determine the success of the LMS from various viewpoints. Hence, educational institutions require a generic instrument that must clearly and consistently measures important LMS success dimensions (Wang et. al., 2007). The primary objective of the current research is to construct a valid and authentic instrument that measures LMS success in all dimensions. Due to the global demand for affordability and availability, many academic institutions are offering their courses to various offshore campuses through virtual learning, and this methodology is accredited as part of the curriculum. In that case, students and academics have no choice but 
to use LMS in their teaching and learning process. Many academics are unaware of the real potential of LMS and only use LMS to disseminate teaching and learning materials to students. This study helps academics to understand the capabilities (creative approaches) of LMS to facilitate students in a better way. The instrument demonstrates an adequate level of internal consistency and validity in each construct. These results will provide better and faster feedback to educational institutions while integrating LMS within their information system.

From the above findings, we can confidentially say that the modern instrument can be used to measure the seven core dimensions of LMS implementation and success: information quality, educational quality, system quality, service quality, intention to use, user satisfaction and net benefits (DeLone \& McLean, 2003). With this instrument, any educational institution across the world can evaluate the outcome of their LMS. Since the instrument was grounded in the various relevant models (DeLone \& McLean, 2003; Holsapple \& Lee-Post, 2006; Lin \& Lee, 2006; Lin, 2007; Hassanzadeh et. al., 2012), the current scale is compatible with those models, and the adopted methodology is good enough to assure a substantial theoretical development in the field of information systems and e-learning. Hence, this study offers an essential contribution to the literature.

Previous studies investigating the model difference between students and academics on e-learning success appear to imply cross-group differences (Arenas-Gaitán et. al., 2018; Hassanzadeh et. al., 2012; Ho \& Dzeng, 2010; Holsapple \& Lee-Post, 2006; Klobas \& McGill, 2010; Lin \& Lee, 2006; Lin, 2007; Wang et. al., 2007; Ozkan \& Koseler, 2009; Ramírez-Correa et. al., 2017; Wang \& Liao, 2008; Wang \& Wang, 2009; Wang et. al., 2014). However, in this study, course administrators were also included as a sample, which will be entirely distinctive from the view provided by students and academics. The samples were collected from two different countries, which also helps to validate the instrument. Accordingly, this study attempts to collect data related to LMS success across two different groups to examine the differences between them, which provides a better methodological contribution for future research.

\section{Conclusion}

LMS success in higher education institutions was constructed from various information system models and is validated in this study. The significant research gaps identified in this study was that most information system success models fail to address the dimensions of educational quality while measuring information system success. Further, the D\&M Information System Success Model was not designed to assess educational success. In this study, we tried to compare the various IS models in an attempt to resolve the gaps in the previous models and to develop a model that measures LMS success in higher education settings. This study concludes that information quality, educational quality, system quality, service quality, intention to use, user satisfaction, and net benefits are the critical constructs for measuring LMS success. In other words, the modified D\&M Information System Success Model (2003) is the best model to determine LMS success by the addition of an extra dimension: educational system quality. The above model constructs were validated with the use of Maldivian and Indian samples, including students, academics, and course administrators. LMS success factor structure and loadings are equivalent across the Indian and Maldivan samples, and model fitness was confirmed. Further studies need to be conducted in various populations, and measurement invariance has to be conducted based on students, academics, and course administrators. This study only proves the validity of the constructs. However, the model link has to be tested, and information system success needs to be measured.

\section{References}

Arenas-Gaitán, J., Rondán-Cataluña, F. J., and Ramírez-Correa, P. E. (2018). Modelling the success of learning management systems: application of latent class segmentation using FIMIX-PLS. Interactive Learning Environments, 26(1), 135-147. https://doi.org/10.1080/10494820.2017.1283335 
Bhuasiri, W., Xaymoungkhoun, O., Zo, H., Rho, J. J. and Ciganek, A. P. (2012). Critical success factors for e-learning in developing countries: A comparative analysis between ICT experts and faculty. Computers and Education, 58(2), 843-855. http://dx.doi.org/10.1016/j.compedu.2011.10.010

Brown, T. A. (2006). Confirmatory factor analysis for applied research. New York, NY: Guilford Press. https://psycnet.apa.org/record/2006-07729-000

Campbell, D. T. and Fiske, D. W. (1959). Convergent and discriminant validation by the multitrait-multimethod matrix. Psychological bulletin, 56(2), 81. http://dx.doi.org/10.1037/h0046016

Cheung, G. W. and Rensvold, R. B. (2002). Evaluating goodness-of-fit indexes for testing measurement invariance. Structural equation modeling, 9(2), 233-255. https://doi.org/10.1207/S15328007SEM0902_5

DeLone, W. H. and McLean, E. R. (1992). Information systems success: The quest for the dependent variable. Information systems research, 3(1), 60-95. https://doi.org/10.1287/isre.3.1.60

Delone, W. H. and McLean, E. R. (2003). The DeLone and McLean model of information systems success: a ten-year update. Journal of management information systems, 19(4), 9-30. https://doi.org/10.1080/07421222.2003.11045748

Fardoun, H., Montero, F. and Jaquero, V. L. (2009). eLearniXML: Towards a model-based approach for the development of e-Learning systems considering quality. Advances in Engineering Software, 40(12), 1297-1305. https://doi.org/10.1016/j.advengsoft.2009.01.019

Fornell, C. and Larcker, D. F. (1981). Evaluating structural equation models with unobservable variables and measurement error. Journal of marketing research, 18(1), 39-50. http://dx.doi.org/10.2307/3151312

Ginns, P. and Ellis, R. A. (2009). Evaluating the quality of e- learning at the degree level in the student experience of blended learning. British Journal of Educational Technology, 40(4), 652-663. https://doi.org/10.1111/j.14678535.2008.00861.x

Hafiz Zakaria, M., Watson, J. and Edwards, S. L. (2010). Investigating the use of Web 2.0 technology by Malaysian students. Multicultural Education and Technology Journal, 4(1), 17-29. https://doi.org/10.1108/17504971011034700

Hagel, J. (1999). Net gain: Expanding markets through virtual communities. Journal of interactive marketing, 13(1), 5565. https://doi.org/10.1002/(SICI)1520-6653(199924)13:1<55::AID-DIR5>3.0.CO;2-C

Hair, J. F., Black, W. C., Babin, B. J., \& Anderson, R. E. (2013). Multivariate Data Analysis. Pearson Education Limited. Retrieved from https://books.google.co.in/books?id=VvXZnQEACAAJ

Hassanzadeh, A., Kanaani, F. and Elahi, S. (2012). A model for measuring e-learning systems success in universities. Expert Systems with Applications, 39(12), 10959-10966. https://doi.org/10.1016/j.eswa.2012.03.028

Ho, C. L. and Dzeng, R. J. (2010). Construction safety training via e-Learning: Learning effectiveness and user satisfaction. Computers and Education, 55(2), 858-867. http://dx.doi.org/10.1016/j.compedu.2010.03.017

Holsapple, C. W. and Lee- Post, A. (2006). Defining, assessing and promoting e- learning success: An information systems perspective. Decision sciences journal of innovative education, 4(1), 67-85. https://doi.org/10.1111/j.15404609.2006.00102.x

Horvat, A., Dobrota, M., Krsmanovic, M. and Cudanov, M. (2015). Student perception of Moodle learning management system: a satisfaction and significance analysis. Interactive Learning Environments, 23(4), 515-527. https://doi.org/10.1080/10494820.2013.788033

Hu, L. T. and Bentler, P. M. (1999). Cutoff criteria for fit indexes in covariance structure analysis: Conventional criteria versus new alternatives. Structural equation modeling: a multidisciplinary journal, 6(1), 1-55. https://doi.org/10.1080/10705519909540118

Kasim, N. N. M. and Khalid, F. (2016). Choosing the right learning management system (LMS) for the higher education institution context: a systematic review. International Journal of Emerging Technologies in Learning (iJET), 11(06), 55-61. http://dx.doi.org/10.3991/ijet.v11i06.5644

Klobas, J. E. and McGill, T. J. (2010). The role of involvement in learning management system success. Journal of Computing in Higher Education, 22(2), 114-134. http://dx.doi.org/10.1007/s12528-010-9032-5

Kühne, R. (2017). Measurement Invariance (Time, Samples, Contexts). The International Encyclopedia of Communication Research Methods, 1-10. https://doi.org/10.1002/9781118901731.iecrm0139

Lee, M. C. (2010). Explaining and predicting users' continuance intention toward e-learning: An extension of the expectation-confirmation model. Computers \& $\quad$ Education, 54(2), 506-516. https://doi.org/10.1016/j.compedu.2009.09.002

Lin, H. F. (2007). Measuring online learning systems success: Applying the updated DeLone and McLean model. Cyberpsychology and behavior, 10(6), 817-820. https://doi.org/10.1016/j.compedu.2009.09.002 
Lin, H. F. and Lee, G. G. (2006). Determinants of success for online communities: an empirical study. Behaviour and Information Technology, 25(6), 479-488. https://doi.org/10.1080/01449290500330422

Baalbaki, I. B., Malhotra, N. K., \& Bechwati, N. N. (2013). Marketing Research: An Applied Orientation. Pearson Education, Limited. Retrieved from https://books.google.co.in/books?id=rWHANAEACAAJ

Ozkan, S. and Koseler, R. (2009). Multi-dimensional students' evaluation of e-learning systems in the higher education context: An empirical investigation. Computers and Education, 53(4), 1285-1296. http://dx.doi.org/10.1016/j.compedu.2009.06.011

Pituch, K. A. and Lee, Y. K. (2006). The influence of system characteristics on e-learning use. Computers and Education, 47(2), 222-244. https://doi.org/10.1016/j.compedu.2004.10.007

Ramírez-Correa, P. E., Rondan-Cataluña, F. J., Arenas-Gaitán, J. and Alfaro-Perez, J. L. (2017). Moderating effect of learning styles on a learning management system's success. Telematics and Informatics, 34(1), 272-286. https://doi.org/10.1016/j.tele.2016.04.006

Nunnally, J. C. (1978). Psychometric theory. McGraw-Hill. Retrieved from https://books.google.co.in/books?id=WE59AAAAMAAJ

Sayfouri, N. (2016). Evaluation of the learning management system using students' perceptions. Medical journal of the Islamic Republic of Iran, 30, 460. https://www.ncbi.nIm.nih.gov/pubmed/28491835

Schaefer, D., Thames, J. L., Panchal, J. H., Haroon, S., \& Mistree, F. (2011). Innovative Design Education in a Global Distance Learning Setting. Paper presented at Mudd Design Workshop VIII, Claremont, California, USA United States. https://researchportal.bath.ac.uk/en/publications/innovative-design-education-in-a-global-distance-learning-setting Schoonenboom, J. (2014). Using an adapted, task-level technology acceptance model to explain why instructors in higher education intend to use some learning management system tools more than others. Computers and Education, 71, 247-256. https://doi.org/10.1016/j.compedu.2013.09.016

Srichanyachon, N., (2014). EFL Learners' Perceptions of Using LMS. Turkish Online Journal of Educational Technology-TOJET, 13(4), 30-35. https://www.learntechlib.org/p/155516/.

Stone, D. E., \& Zheng, G. (2014). Learning Management Systems in a Changing Environment. In V. Wang (Ed.), Handbook of Research on Education and Technology in a Changing Society (pp. 756-767). Hershey, PA: IGI Global. https://doi.org/10.4018/978-1-4666-6046-5.ch056

Wang, Q., Woo, H. L., Quek, C. L., Yang, Y. and Liu, M. (2012). Using the Facebook group as a learning management system: An exploratory study. British Journal of Educational Technology, 43(3), 428-438. https://doi.org/10.1111/j.1467-8535.2011.01195.x

Wang, W. T., and Wang, C. C. (2009). An empirical study of instructor adoption of web-based learning systems. Computers and Education, 53(3), 761-774. http://dx.doi.org/10.1016/j.compedu.2009.02.021

Wang, Y. S. and Liao, Y. W., (2008). Assessing eGovernment systems success: A validation of the DeLone and McLean model of information systems success. Government information quarterly, 25(4), 717-733. https://doi.org/10.1108/OIR-04-2014-0097

Wang, Y. S., Li, H. T., Li, C. R., and Wang, C. (2014). A model for assessing blog-based learning systems success. Online Information Review, 38(7), 969-990. https://doi.org/10.1016/j.giq.2007.06.002

Wang, Y. S., Wang, H. Y. and Shee, D. Y. (2007). Measuring e-learning systems success in an organizational context: Scale development and validation. Computers in Human Behavior, 23(4), 1792-1808. https://doi.org/10.1016/j.chb.2005.10.006

Weaver, D., Spratt, C., and Sid Nair, C. (2008). Academic and student use of a learning management system: Implications for quality. Australasian journal of educational technology, 24(1). https://doi.org/10.14742/ajet.1228

\section{Appendix A. Questionnaire items}

\section{Technical System Quality}

1. Learning Management System availability is very high

2. Learning Management System is easy to use

3. Learning Management System is user-friendly

4. Learning Management System provides high-speed access to Information

5. The Learning Management System has attractive features to appeal to the users

6. Learning Management System is reliable and secured 


\section{Educational System Quality}

1. Learning Management System is appropriate with students' learning styles

2. Learning Management System provides collaborative and active learning

3. Learning Management System offers interactive features between users and system

4. Learning Management System delivers the possibility of evaluation of learning and performance

5. The Learning Management System provides a personalized information presentation

\section{Information Quality}

1. I think course content is always presented in a useful format

2. Learning Management System provides up-to-date information

3. Learning Management System provides course accurate content/information

4. Learning Management System provides precise content/information

5. The Learning Management System provides the content you need at the right time

6. The Learning Management System provides information that is easy to understand

7. Learning Management System provides organized content/information

8. The course content is presented in a useful format

\section{Service Quality}

1. The IT department/e-learning support staff provides a proper level of assistance and explanation

2. The IT department/e-learning support staff are always available for consultation

3. The IT department/e-learning support staff provide satisfactory support to users using the Learning Management System at College/ University

4. The Learning Management System developers interact extensively with users during the development of the e-learning system

5. The IT department/e-learning support staff responds cooperatively to your suggestion for future enhancements of the Learning Management System

\section{Intention to Use}

1. The frequency of using Learning Management System is high

2. If Learning Management System were not mandatory, I would still use it

3. I spend many hours per week with the Learning Management System

4. Assuming I have access to the Learning Management System, I intend to use it

5. The Learning Management System usage is voluntary

6. I depend on the Learning Management System

\section{User Satisfaction}

1. The Learning Management System is efficient

2. The Learning Management System helps to gain my confidence

3. The system is adequate to meet the educational needs of the users

4. Most of the users bring a positive attitude or towards the Learning Management System function

5. I think that the perceived utility about the Learning Management System is high

\section{Net benefit}

6. Over-all, I am satisfied with the system performance

1. The Learning Management System helps me improve my learning performance

2. The Learning Management System helps me think through problems

3. The Learning Management System enables the College/University to respond more quickly to change regarding teaching and learning

4. The Learning Management System helps to enhance the competitiveness of the College/University

5. The Learning Management System allows the College/University to save cost relating to teaching and learning

6. The Learning Management System helps the College/University to speed up transactions or shorten product cycles (change the words)

7. The Learning Management System helps the College/University increase return relating to teaching and learning investment

8. The Learning Management System helps the College/University to achieve its goal 